\title{
Double Homeobox Protein 4
}

National Cancer Institute

\section{Source}

National Cancer Institute. Double Homeobox Protein 4. NCI Thesaurus. Code C97465.

Double homeobox protein 4 ( $424 \mathrm{aa}, \sim 45 \mathrm{kDa}$ ) is encoded by the human DUX4 gene.

This protein plays a role in the regulation of transcription. 